\title{
Identification and Measurement of the Factors Affecting Satisfaction Level of Smart Phone Users: Empirical Evidence from Bangladesh
}

\author{
Shobod Deba Nath ${ }^{1}$, Anup Kumar Saha ${ }^{2} \&$ Md. Akram Hossain ${ }^{3}$ \\ ${ }^{1}$ Department of International Business, University of Dhaka, Bangladesh \\ ${ }^{2}$ Department of Accounting \& Information Systems, Jagannath University, Bangladesh \\ ${ }^{3}$ Department of Management Information System, University of Dhaka, Bangladesh \\ Correspondence: Shobod Deba Nath, Department of International Business, University of Dhaka, Bangladesh. \\ E-mail: subodh154du@yahoo.com
}

Received: December 17, 2014

Accepted: February 12, $2015 \quad$ Online Published: March 27, 2015

doi:10.5539/ijbm.v10n4p166

URL: http://dx.doi.org/10.5539/ijbm.v10n4p166

\begin{abstract}
This study identifies and measures of the factors affecting satisfaction level of Samsung smart phone users. A total of 100 university's students are surveyed by applying stratified sampling procedures. Bivariate correlation and multiple regression analysis technique have been applied for testing the hypothesized associations. The study finds that among five independent variables, only two variables (technical and value-added services) are significant and have an impact on customer satisfaction level toward using Samsung smart phone whereas value-added service has most influence on creating satisfaction for smart phone users, followed by technical service. In addition, another finding indicates that there exists a significant positive correlation between the customer satisfaction and customer loyalty, that is, high level of Samsung smart phone users' satisfaction is correspond with a heightened likelihood towards Samsung brand loyalty. Finally, this study has embark on to assist marketing managers better understand the key drivers (value added and technical services or attributes) of Smart Phone in order to generate and uphold user satisfaction as well as fidelity in an extremely intricate marketplace.
\end{abstract}

Keywords: customer satisfaction, brand loyalty, smart phone, Samsung, Bangladesh

\section{Introduction}

The present world is the world of information technology. The blessing of information technology has touched almost all of the countries of the world. As a developing country Bangladesh is also blessed with the contribution of information and communication technology. Mobile phone is one of the revolutionary inventions of modern science and technology that has enriched our communication network. It has now been possible to communicate from one corner to another by using this wonderful technology. Mobile phone, with its contribution, has improved the standard of living of people. Before invention mobile phone Telegraph was only one medium of communication. Alexander Graham Bell invented telephone in 1876. As a result, it has been possible to send the human voice to the remote place of the world. Electric sign is flown through the wire of both the telegraph and telephone. At the beginning of last century wireless was invented by Marcony, which brought revolutionary changes in the communication systems. Consequently, the necessity of adding wire by receiving \& transferring not needed. In case of telephone it is set up one place which is not transferable, so problem occurs. In this situation mobile phone takes the place of telephone to overcome the problem.

The use of mobile phone is dramatically amplified in our Bangladesh because of the reduction of price of mobile phone. People can now purchase mobile phone at a very lower price. Majority people in the telecommunication market purchased and consumed mobile phone is known as basic phone. In essence, basic phones are mainly used for the purpose of communication voice and messaging short text services (i.e., SMS) along with controlled browsing (Subramanian, 2009). Rice and Katz (2008) indicated that the cell phone might be recognized as the digitally social platform that has the capability of acquiring, providing and sharing private and group information. Nevertheless, Smartphone has been treated as new improved technology in the marketplace. The basic difference between a smart phone and a cell phone is to find out the fact whether or not the phone uses any specific mobile operating system. Conventionally cell phone does not have any operating systems. On the other hand, smart 
phones are operated by a combination of systems including windows mobile, iPhone operating system, symbian operating system, google android or linux which permits third party application to run on it (Sanne, 2009). Smartphone is much closer to becoming the nearly ubiquitous environment that holds out an enormous potential for promising on-demand access to contents anytime and anywhere access to anything. It is expected that smart phone may allow for various interactions that would benefit both businesses and consumers as aspect of the interactive medium. As a result, majority consumers have rapidly switched their purchasing tendency from cell phone to smart phone.

For decades, handset makers have cared for mobile network operators as the entrance to their networks alongside put in order the type of phones to be produced, their costs, and the existing attributes. Mobile network operators have chiefly versioned handsets as economical, non-refundable entices that have been extraordinarily promoted to capture subscribers and hold them by the use of privately owned services. Nevertheless, the Samsung smart phone has disappointed that balance of power. Mobile network operators have learnt that despite high price, a smart phone can be able to draw consumer's attention along with improved sales. At present, the demand for premium branded smart phones like the apple iPhone, Samsung, HTC, Sony etc has been getting higher. Majority consumers demand for multifaceted attributes and benefits within one device. These are the reasons behind speedy expansion of the sales of smart phones as well as increased competition in the telecommunication market.

Usually, handset manufactures have investigated various studies in order to portray users' contentment, and discovered the process of using products, be acquainted with apparent product-related wants, and concentrated on product attributes with the purpose of fulfilling those wants. Despite a detailed previous investigation into this area, it is yet to make great endeavour to discover the full range of users' silent needs and wants. The speedy progresses in information and communication technology bring huge advantages for today's organizations in order to create and retain prolonged sustainable connections with their consumers than earlier. The prime target of any handset manufacturers is to convert those sustainable connections into huge margin through lessening costs associated with consumer acquirement, reiterating purchases and brining differentiation. Only basic service is no longer considered as a differentiation tool indented to amplify consumer contentment. Besides, mobile network operators have been progressed with sophisticated technology as well as discovering better updated product offerings. The rivalry within the telecommunication industry has been growing. Even with the advent of globalization, the nature of competition in the mobile phone and telecommunication related industries is now very elevated. What necessary steps should these organizations undertake in order to thrive in this complex marketplace? With the passage of time, organizations have come to realize the fact that firm's profitability and performance can only able to get better through concentrating more on keeping existing consumers that attracting new consumers in the mature telecommunication related industries. Since the competitive marketplace brings an escalating variety of chances for consumers, how mobile telecommunications service providers can ensure customer satisfaction which leads to customer loyalty?

The paper investigates and measures key factors that affect the level of satisfaction toward using smart phone users in Bangladesh. In doing so, this paper examines the relationship between factors and customer satisfaction toward using smart phone users with particular attention to Samsung. The specific objectives are - to identify the current level of satisfaction toward using "Samsung smart phone"; to find out the factors affecting level of satisfaction toward using "Samsung smart phone"; to measure the influence of those factors towards the use of "Samsung smart phone"; and finally, to draw a relationship between factors and customer satisfaction toward using "Samsung smart phone".

Questions to be answered through this research are of two types- qualitative and quantitative. Research questions of qualitative nature are-what are the factors contributing to customer satisfaction? Does product satisfaction prompt customer loyalty? Whereas, the quantitative questions to be asked are-To what extent do these factors influence levels of satisfaction to for Samsung smart phone users in Bangladesh? Do high levels of satisfaction for users correspond with a heightened likelihood towards customer loyalty?

\section{Review of Literature}

The idea of consumer satisfaction has gained huge interest in recent times in telecommunication industry. For every firm, consumer satisfaction is the vital aspect that needs careful attention. This is mainly due to the increased significance of the fact that superior consumer contentment can lead to a strong position in the rivalry marketplace by means of declining price elasticity, falling business costs, lessening failure costs along with reducing the all the expenses of acquiring new consumers (Fornell, 1992). According to (Brown et al., 1992), a buyer can satisfy about a product or service if the product or service can able to meet his/her desires and 
priorities. And a buyer will be elated if the product or service exceeds his/her expectations. They have also found that even elated buyers are becoming loyal to the product or the firm, insensitive to price and talk favourably about that firm. In addition, they have mentioned that organization must have pay attention to their customers and provide appropriate services to satisfy them. Besides, buyer contentment usually refers to buyer reaction "to the state of fulfilment, and customer opinion of the fulfilled condition" (Oliver, 1997).

According to Hossain et al. (2012), switching cost and length of relationship have a positive and significant influence on customers' switching resistance, while other factors such as trust, perceived satisfaction and corporate image are not as critical to the outcome. Firms can achieve buyer contentment by gratifying their customers' desires and priorities (La Barbera \& Mazursky, 1983). Moreover, buyer contentment refers to the buyer's combined idea of an organization's service outcome (Johnson \& Fornell, 1991). Likewise, Zeithaml \& Bitner (2003) have indicated that satisfaction is termed as the buyer's assessment of product or service after consumption. Kotler (1997) defines customer satisfaction as an individual's feelings of enjoyment or disenchantment resultant from judging against a product's perceived result with regard to his or her wishes.

Customer satisfaction is an important issue nowadays for organizations for improving product $\&$ service quality, and maintaining customer loyalty in this highly cutthroat competition (O'Loughlin \& Coenders, 2002). A critical motivation for the increasing stress on customer satisfaction is that higher customer satisfaction can lead to higher market share and profit by means of superior competitive position (Fornell, 1992). Customer satisfaction is acts as a significant determinant of customer loyalty. Satisfied customers work as ambassadors for the product or service through word to mouth marketing (Fornell et al., 1996). This satisfaction in customers' end works in benefit of the firm in increase of reputation, reduction of price elasticity, lower costs of future transactions, and higher employee efficiency (Anderson et al., 1994; Fornell, 1992). For consumer researchers the issue of customer satisfaction is very important (Fournier \& Mick 1999; Meuter et al. 2000). According to Patterson (1993) quoted from Goode (2005), customer satisfaction is a vital consideration for all those organizations that wish to create and keep a competitive advantage in present competitive scenario. Moreover, customer satisfaction also supplies crucial responses regarding the marketing decisions quality and is widely recognized as a vital factor in moulding customers' future buying intensions (Taylor \& Baker 1994). Richen (1983) also supports word to mouth marketing by the positive experiences of the satisfied customers. Fournier and Mick (1999) defined customer satisfaction as a judgment that a customer develops after purchasing or coming a product or service. Szymanski and Henard (2001) identified some well established determinants of customer satisfaction such as expectations, disconfirmation of expectations, performance, affect and equity. Customers are said to be satisfied when actual performance outcome exceeds expectation (positive disconfirmation), and dissatisfaction arises when expectation exceeds performance outcome (negative disconfirmation) (Goode et al, 2005). Customers' satisfaction level varies depending on the alternatives available in the market (Afroz et al., 2010).

As the assessment of satisfaction is expected to be based on a wide array of matters, there can be possibly numerous factors of customer satisfaction as the extent underlying satisfaction measurements are inclusive rather than precise (Rust and Oliver 1994). Almossai (2012) identified costs and reserves (i.e., rents, charges) are the largest part noteworthy in influencing satisfaction, retention, and possibility of switching from one service operator to other one. Moreover, Grapentine (1995) found some attributes (charge, brand awareness, quality, comfort and design) of determinants in shaping potential outcome. For instance, attitude toward a particular brand has been revealed to be noteworthy feature in building potential performance as the brand name is well known to the buyers rather than all other brand features (Doods et al. 1991). Turnbull et al. (2000) indicated that shoppers favored to purchase renowned brands as they sought to cut down their purchasing ambiguity. In addition, shoppers profoundly depended on other satisfied shoppers' judgments and word of mouth throughout the consumption process (Turnbull, et al. 2000). Goode et al. (2005) identified some features that may perhaps build performance expectations include brand perceptions, level of service charges and the price of the mobile phone. Furthermore, Turnbull et al. (2000) mentioned variations in purchasing criteria among diverse gender and age groups. Males treated reliability and brand loyalty to be key factors in respect of females who treated expert image and quality as vital. On the other hand, younger consumers (aged 18-24), treated brand image, fashion and trendiness are the key determinants during the time of purchase decision making.

Uddin and Akhter (2012) clearly revealed the practical outcomes on a recent study that service excellence and fair charge have not direct influence on customer satisfaction of a mass service industry (i.e., mobile phone operators) through perceive value. Grameen Phone has been doing well in order to form a distinct reputation with various added benefits compared to its rivalry in the marketplace and the consumers are consistently pleased with the preliminary charge of GP connections, handsets and network (Hossain et al). Goode (2005) 
identified some foremost rationales for these high growth rates in mobile phones: firstly, highly consistent technology; secondly, the capacity to be used nearly everywhere; thirdly, user friendliness of receiving and sending voice and text messages, fourthly, expanded network coverage, fifthly, the capacity to accumulate contact numbers, sixthly, inexpensive way of send text messages; and finally, the capacity to entrance the web using internet.

An important factor distinguishing smart phones from existing feature phones (contemporary basic phone without advanced computing ability and internet connectivity) is that a smart phone permits the consumers to set up and run most sophisticated applications with PDA-like (and even computer-like) features all through fast wireless web connection (Younghoon Chang, 2011). Smart phones are dramatically reshaping the competition within the mobile industry. Wireless delivery of applications and great contents depend completely on what platform smart phone uses. Now the number of users may consider a smart phone not for the network it runs on or for what functions are built in but for what kinds of applications will run on it. Thus formerly separate mobile telecoms service industry architecture and their associated organizations are being enforced into straight contest in the growing mobile operating system race, coming across value capture and user lock-in approaches.

Recent studies have also pointed out that a platform is the results of a set of business behaviors and associations between forces in an ecosystem. And there exists strong levels of interdependence between forces (Gawer \& Cusumano, 2002; Gawer, 2009). There are largely two groups in smart phones platform: open versus closed platform. The iPhone platform is closed, and the entire ecosystem is controlled by one company, Apple. On the other hand, Android presents developers the capacity to assemble enormously affluent and novel applications through ensuring an open development platform (Younghoon Chang, 2011). Namely, while Android appears to give more role of the number of participations motivated by market power while iPhone platform has interested in high-end market, showing high level of loyalty with Apple (Kim \& Chang, 2011).

In order to effectively gain an advantage over competitors, customer satisfaction should be measured and evaluated regularly (Patterson, 1993). Identification and measurement of the factors affecting satisfaction level of smart phone users in the Bangladesh are relevant due to the fluctuating nature of the highly competitive market. With insight on consumer satisfaction levels Samsung may be able to maintain the current growth and gain a larger Bangladesh market share in comparison to its competitors (i.e., Apple iphone, HTC and so on). There are several national consumer satisfaction indexes that have been developed. These include the Swedish customer satisfaction barometer (Fornell, 1992) the ACSI (Fornell et al., 1996; see figure 1), and the Norwegian Customer Satisfaction Barometer (Andreassen \& Lindestad, 1998). Mustafa Ally and Michael Gardiner (2012) proposed a hybrid smart mobile device acceptance model which is shown in figure 2 .

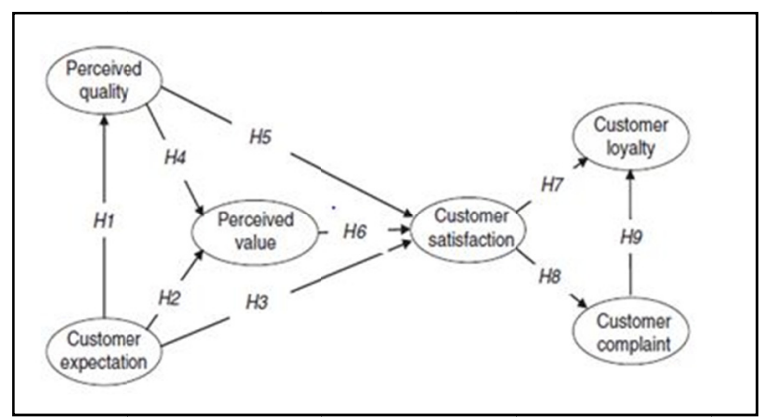

Figure 1. ACSI model for Jordanian mobile phone sector (Fornell et al., 1996; Awwad, 2011) 


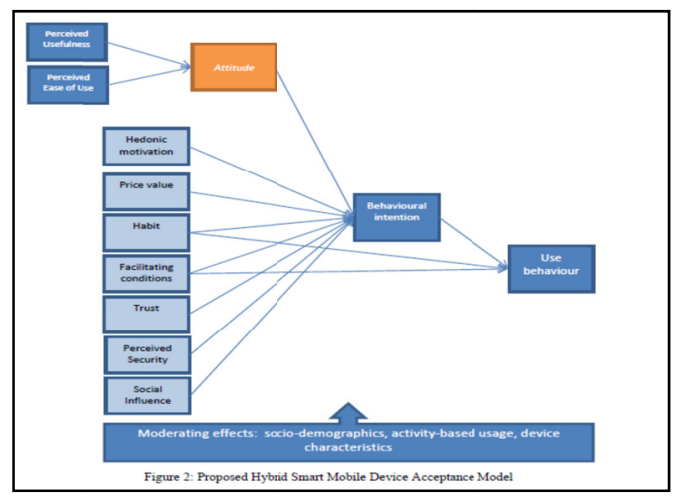

Figure 2. Hybrid smart mobile device acceptance model (Alley \& Gardiner, 2011)

While there are countless consumer satisfaction indices to model, this research was conducted using a multi-criteria approach as identified by Gulfem Iskilar and Gulcin Buyukozkan in figure 3 (Isiklar and Buyukozkan, 2007). This research gives insight on mobile phone selections based on main criteria and sub-criteria.

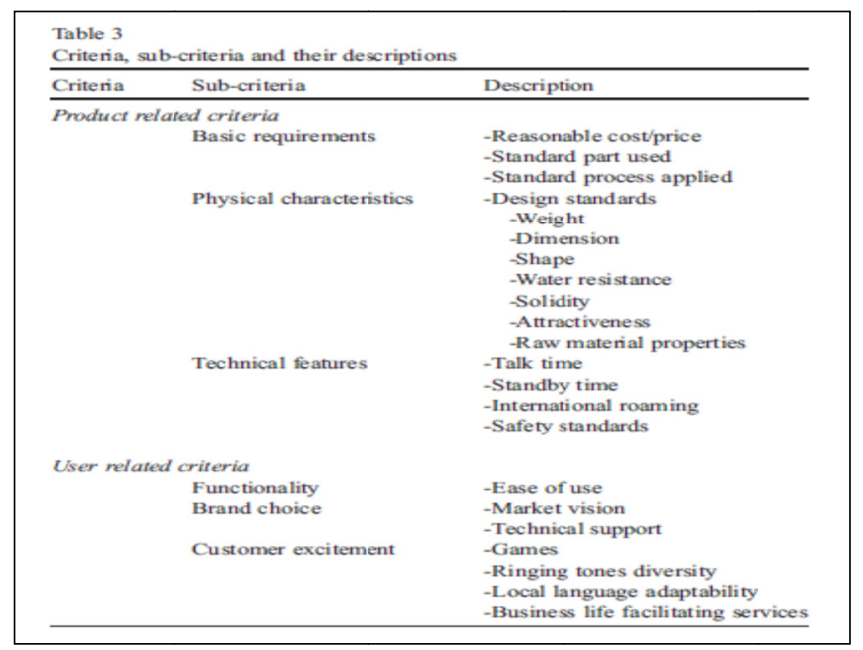

Figure 3. Criteria for evaluating a mobile phone during purchase decision making (Isiklar \& Buyukozkan, 2007).

These categories are reflected in Figure 3. Using this model, one can ultimately determine the weight of these characteristics on purchase decisions for mobile phones (Chuang et al., 2001; Ally \& Gardiner, 2012). In addition, multiple variables relating to the product can be evaluated on a pre-determined scale to measure overall satisfaction (Han et al., 2004; Lee, 2011).

Overall, the literature suggests that key drivers affecting customer satisfaction with and loyalty to smart phone companies need to be better understand. From the above studies, it can be noticed that there are various factors that affect the level of customer satisfaction. Several researches have been conducted to identify and measure the factors affecting the level of customer satisfaction of mobile phone service companies in Bangladesh. However, the researchers did not find any study on identification and measurement of the level of satisfaction of smart phone users in Bangladesh.

Conceptual Framework and Hypotheses Development: Therefore, to carry out this particular study in order to fill the gap, the researchers develop a conceptual framework as well as intended to test two important hypotheses for the purpose of investigating the factors that affect the level of satisfaction of smart phone users in Bangladesh. The conceptual framework and research hypotheses associated with customer satisfaction are given below: 


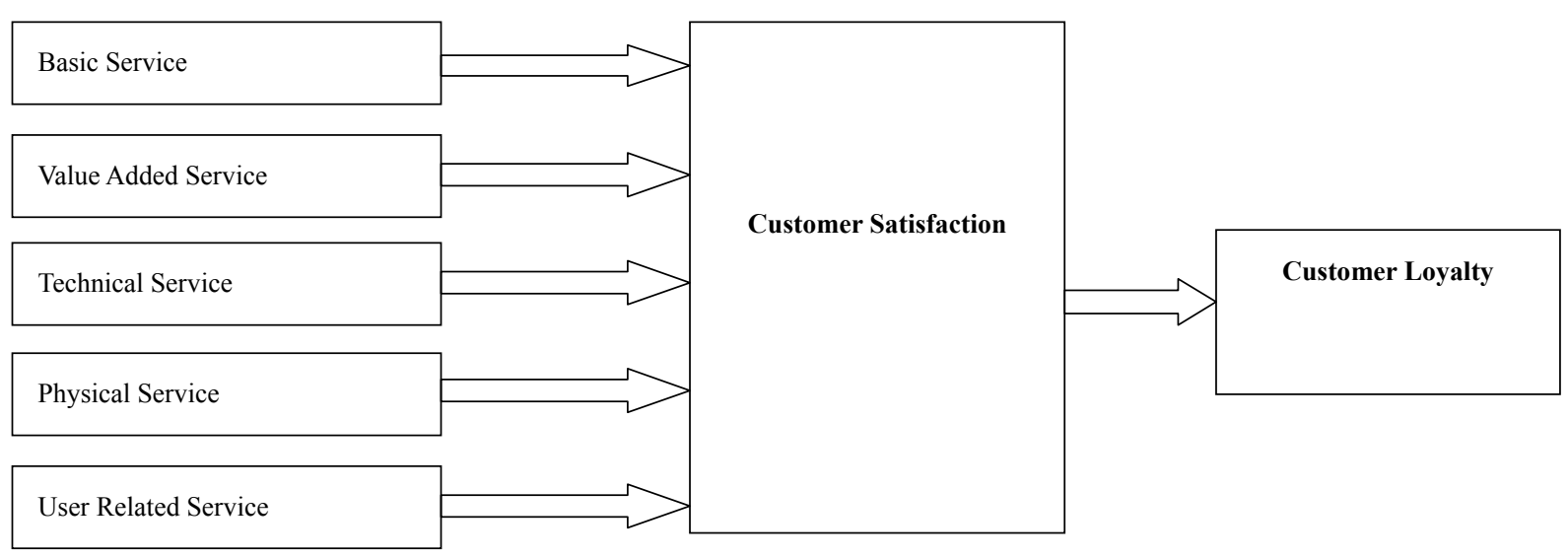

Figure 4. Conceptual framework (source: authors' construct)

Hypothesis 1: Samsung smart phone users in the Bangladesh are exposed to multiple variables upon purchase and experience of the mobile device that directly influence customer satisfaction.

Hypothesis 2: Customer satisfaction for Samsung smart phone users has positive relationship toward customer loyalty (future purchase as well as recommend others through word-of-mouth).

\section{Methodology}

\subsection{Type of Research Design and Data Collection Methods}

This study emphasised only on a homogeneous group of undergraduate and postgraduate students between age of 23 and 30. The type of research design was descriptive in nature wherein a mixed method was followed with the purpose of collecting and analyzing data. At the first stage, the identification of variables was done based on exploratory research methods such as secondary data analysis and expert surveys alongside a 40-60 minutes focus group discussion. At the second stage, the study was carried out following the descriptive research design to test relative significance of each of the factors affecting the level of satisfaction of smart phone users in Bangladesh.

\subsection{Sampling Technique and Sample Size}

A total number of 100 students were selected from different universities randomly for samples by using probability sampling technique that is simple random sampling. Although all universities (thirty two public universities alongside fifty seven private universities) situated geographically across different districts in Bangladesh, only public and private universities placed at Dhaka city were considered as sampling units. The universities registered lists of students were used as the sampling frame wherein students who used 'Samsung' branded smart phone were considered as sampling elements.

\subsection{Measuring Instrument and Variable Specifications}

A measuring instrument i.e. structured survey questionnaire was administered through personal interview and the information needed for this research was related to the factors affecting the level of satisfaction of smart phone users in Bangladesh. A draft questionnaire was prepared for data collection on basis of variable specified in this study. Since there was absence such related study in the context of branded smart phone users in Bangladesh, the authors considered all dependent and independent variables based on previous research from developed country perspective. There were a total of seven variables including 25 items. Among them, five are independent variables (basic service; value added service; technical service; physical service; user related service) and two are dependent variables ("customer satisfaction" \& "customer loyalty"). For measurement purposes, a 7-point Likert-type interval scale with $1=$ highly disagree and $7=$ highly agree was used. The items used in questionnaire were adopted from previous studies (Alshurideh et al., 2012; Awwad, 2011; Taylor \& Baker, 1994).

\subsection{Reliability and Validity}

The authors had been checked the reliability and validity of this questionnaire using various theories such as Nunnally's (1967) threshold of 0.70 and above, and pre-testing on a small sample. As the scale items had already used in previous surveys, pre-testing of the questionnaire was limited to only few sample respondents to ensure the precision, conciseness, objectivity, and understandability of the questions. Multicollinearity problem had been checked by calculating the value of VIF and TL. The model will be free from multicollinearity problem if it meets 
two conditions ( $\mathrm{VIF}<10$ and Tolerance level $>.10)$.

\subsection{Fieldwork}

A total of four fieldworkers participated in the data collection activity. The author is responsible for the control of the fieldwork conducted. Moreover, the survey had been conducted in Dhaka from the period 01 December, 2014 to 15 December, 2014.

\subsection{Data Analysis}

The collected data were tabulated on the computer and the final analysis was performed by using different statistical techniques namely frequency distribution, cross tabulation, correlation and regression analysis via SPSS 20.0 package program. Since there are more than two independent variables in this study, an ideal quantitative technique particularly "multiple regression analysis" has been conducted. The purpose of this analysis was to measure the relative influence of each independent variable on the dependent variable. The regression models used were as follows:

$\mathbf{Y}=\boldsymbol{\beta 0}+\boldsymbol{\beta 1 B S}+\boldsymbol{\beta 2 V A S}+\boldsymbol{\beta 3 T S}+\boldsymbol{\beta 4 P S}+\boldsymbol{\beta 5 U R S}+\mathbf{e i}($ where, $\mathrm{Y}=$ customer satisfactory $; \mathrm{BS}=$ basic service; $\mathrm{VS}=$ value added service; $\mathrm{TS}=$ technical service; $\mathrm{PS}=$ physical service; $\mathrm{URS}=$ user related service, $\mathrm{ei}=$ Error $)$

$\mathbf{Y}=\boldsymbol{\beta 0}+\boldsymbol{\beta 1 C S}+\mathbf{e i}($ Where, $\mathrm{Y}=$ customer Loyalty; $\beta 0=$ Constant; $\mathrm{CS}=$ customer satisfaction; $\mathrm{ei}=$ Error)

The coefficients associated with each of the independent variables are denoted by $\beta$. This coefficient denotes how much relationship exists between that particular independent variable and the dependent variable. The $\beta$ values of each independent variable has considered as group parameter. If the $\beta$ of all independent variable is same that it means the independent variables have no effect on the dependent variable, that means, the null hypothesis is accepted. But if the $\beta$ of all the independent variables are not same then it can be said that the null hypothesis is rejected and automatically the alternative hypothesis would be accepted. This study also used the $\mathrm{R} 2$ value to test hypothesis. If this value is 0 , then it can be said that there is no relationship among the dependent and independent variables. If not, then there are some relationships among the variables, which mean it can reject the null hypothesis and accept alternative hypothesis.

\section{Analysis, Interpretations and Findings}

\subsection{Reliability Test}

Scale reliability was tested using Cronbach alpha scores, the values of which were calculated for each scale to test for internal consistency. All constructs appeared to be robust and acceptable as they easily exceeded Nunnally's (1967) threshold of 0.70. (Basic Attributes, $a=.751$, Physical Attributes, $a=.804$, User Related Attributes, $\mathrm{a}=.770$, Technical attributes, $\mathrm{a}=.775$, Value-added Attributes $=.756$; see appendix).

\subsection{Multiple Regression Analysis}

Table 1. Model summary for Samsung smartphone

\begin{tabular}{|c|c|c|c|c|c|c|c|c|c|c|}
\hline \multirow[b]{2}{*}{ Model } & \multirow[b]{2}{*}{$\mathbf{R}$} & \multicolumn{9}{|c|}{ Change Statistics } \\
\hline & & R Square & $\begin{array}{l}\text { Adjusted } \\
\text { Square }\end{array}$ & $\begin{array}{c}\text { R Std. Error } \\
\text { the Estimate }\end{array}$ & $\begin{array}{l}\text { f R Square } \\
\text { Change }\end{array}$ & F Change & df1 & df2 & $\begin{array}{l}\text { Sig. } \\
\text { Change }\end{array}$ & $\mathbf{F}$ \\
\hline 1 & $.659^{\mathrm{a}}$ & .435 & .404 & 1.008 & .435 & 14.447 & 5 & 94 & .000 & \\
\hline
\end{tabular}

a. Predictors: (Constant), ValueAdded_service, Basic_service, User_service, Physical_service, Technical_service.

b. Dependent Variable: Overall, how satisfied were you after using Samsung smart phone.

Here, the Table 1 shows the value of correlation coefficient, $r=0.659$; which implies that there exists a high degree of positive relationship between dependent variable (customer satisfaction) and independent variables (basic service; value added service; technical service; physical service; and user related service). Here, R2 = .435; which implies that $43.5 \%$ of the total variation of the customer satisfaction toward purchasing Samsung smart phone can be explained by the regression model (by the variation in factors influencing customer satisfaction). Thus, fitness of the model is $43.5 \%$. In addition, the value of adjusted R2 is $.404(40.4 \%)$ which represents the fact, after adding addition variables or factors cannot produce any additional significant role in case of producing customer satisfaction toward purchasing Samsung smart phone.

Overall, based on the statistical representation $[\mathrm{R}=.659 ; \mathrm{R} 2=.435$; Adjusted $\mathrm{R} 2=.404 ; \mathrm{F}(5,94)=14.447 ; \mathrm{p}<.05$ 
(.000)] seen above Table 1, it can be also concluded that hypothesis 1 has been accepted at $5 \%$ significant level since the value of significance is less than $0.05(p=.000)$. The independent variables here explain $40.4 \%$ of the variance in the customer satisfaction level of Samsung smart phone users.

Table 2. Coefficient for Samsung smartphone

\begin{tabular}{|c|c|c|c|c|c|c|c|c|}
\hline & & \multicolumn{2}{|c|}{$\begin{array}{l}\text { Unstandardized } \\
\text { Coefficients }\end{array}$} & \multicolumn{3}{|l|}{$\begin{array}{l}\text { Standardized } \\
\text { Coefficients }\end{array}$} & \multicolumn{2}{|c|}{$\begin{array}{l}95 \% \text { Confidence } \\
\text { Interval for } \mathrm{B}\end{array}$} \\
\hline \multicolumn{2}{|c|}{ Model } & B & Std. Error & Beta & $\mathbf{t}$ & Sig. & Tolerance & VIF \\
\hline \multirow[t]{6}{*}{1} & (Constant) & -.553 & .858 & & -.645 & .521 & .565 & 1.770 \\
\hline & Basic_Service & .093 & .105 & .092 & .888 & .377 & .603 & 1.657 \\
\hline & Physical_Service & -.055 & .093 & -.060 & -.598 & .551 & .515 & 1.943 \\
\hline & Technical_Service & .381 & .142 & .289 & 2.675 & .009 & .728 & 1.373 \\
\hline & User_Service & -.049 & .109 & -.041 & -.452 & .653 & .584 & 1.711 \\
\hline & Value Added_Service & .732 & .166 & .449 & 4.422 & .000 & .565 & 1.770 \\
\hline
\end{tabular}

a. Dependent Variable: Overall, how satisfied were you after using Samsung Smartphone.

According the Table 2, only two independent variables (technical and value-added services) are significant and have an impact on customer satisfaction level toward using Samsung smart phone whereas value-added service (44. 9\%) has most influence on creating satisfaction for smart phone users, followed by technical service (28.9\%). Some of the prior researches related to this said area also support this empirical finding (Alshurideh et al., 2012; Awwad, 2011; Taylor \& Baker, 1994). Besides, it can be said that other factors such as basic service, user related service, physical service do not produce much more influence toward using smart phone. Even most of the competitors like Apple iphone, HTC, Nokia are competing in smart phone industry by providing value added and technical service. However, the model results are correct because there is no multicollinearity problem since the value of VIF is less than $10 \&$ the level of tolerance is greater than .10 (i.e., VIF $<10$ and Tolerance level >.10)

\subsection{Bivariate Correlation Analysis}

Table 3. Correlations between customer satisfaction and customer loyalty

\begin{tabular}{llll} 
& & \\
\multicolumn{2}{l}{ Bivariate Correlations } & Overall Satisfaction & Customer Loyalty \\
\hline Overall & Pearson Correlation & 1 & $.360^{* *}$ \\
Satisfaction & Sig. (2tailed) & & .000 \\
& $\mathrm{~N}$ & 100 & 100 \\
& Customer Loyalty Pearson Correlation & $.360^{* *}$ & 1 \\
& Sig. (2-tailed) & .000 & 100 \\
\hline
\end{tabular}

**Correlation is significant at the 0.01 level (2-tailed).

Here, independent variable represents overall satisfaction level toward using Samsung smart phone whereas dependent variable represents customer loyalty toward Samsung smart phone. Based on the statistical representation $[\mathrm{R}=.360, \mathrm{p} \leq .05,(.000)]$ above in the table, we conclude hypothesis $\mathbf{2}$ has accepted as there exists a significant positive correlation between the customer satisfaction and customer loyalty.

\section{Conclusion and Future Research Directions}

In conclusion, Samsung smart phone users generally have positive attitudes towards the brand along with its related service attributes. According to the qualitative and quantitative investigation conducted in this research, technical services and value added services (such as Apps) are the most affective attributes toward customer satisfaction. Laugesen and Yuan (2010) suggested that Samsung formed a thriving leg to amplify user curiosity in mobile services through novel applications (i.e., formed user demand) while abridge the procedure for 
software developers through the beginning of a "Software Development Toolkit". In addition, one of the findings demonstrates significant positive relationship between satisfaction and loyalty of smart phone users. Moreover, Firat and Dholakia (2006) mentioned that smart phone customers did not passively accept the value propositions presented by the Samsung rather they uniquely experienced and created value within their own social contexts. Furthermore, customers became active players in the value co-creation process who influenced where, when and how value was created. Finally, this study has embark on to assist marketing managers better understand the key drivers (value added and technical services or attributes) of Smart Phone in order to generate and uphold customer satisfaction as well as fidelity in an extremely intricate marketplace.

This study has a few shortcomings. First of all, the sample size used for the data analysis is not representative in terms of number $(\mathrm{n}=100)$ and diversification although Wahid et al. (2011) suggested that a sample size between 30 and 500 at $5 \%$ confidence level is usually adequate for a quantitative study. Secondly, the sample was collected from a homogeneous group of undergraduate and postgraduate students between age of 23 and 30 which overlooked the diversity of the respondents. Then, it is also noted from the findings that customers experiencing a high level of satisfaction have strong customer loyalty toward Samsung smart phone brand. However, some other potentially influential factors affecting customer loyalty are also required to be analyzed such as the switching barrier (Gerpott et al., 2001). Although the level of customer satisfaction keeps constant, the level of customer loyalty may vary a lot according to the magnitude of the switching barriers such as loss-cost, adaptation cost and move-in cost.

Further study should enlarge to heterogeneous samples in terms of other demographics age group, occupation, and income with the purpose of making confirm this model's complete appropriateness to other context. In addition, further antecedent variables (psychological factors) may possibly be experienced within this modeling structure in an endeavor to progress the extrapolative precision of the model.

\section{References}

Ally, M., \& Gardiner, M. (2012). The moderating influence of device characteristics and usage on user acceptance of Smart Mobile Devices. 23rd Australasian Conference on Information Systems Smart Mobile Device Adoption 3-5 Dec 2012, Geelong.

Alshurideh, M., Masadeh, R., \& Alkurdi, B. (2012). The Effect of Customer Satisfaction upon Customer Retention in the Jordanian Mobile Market: An Empirical Investigation. European Journal of Economics, Finance and Administrative Sciences, 47, 69-77.

Awwad, M. S. (2011). An application of the American Customer Satisfaction Index (ACSI), in the Jordanian mobile phone sector. The TQM Journal, 24(6), 529-554. http://dx.doi.org/10.1108/17542731211270098

Chuang, M. C., Chang, C. C., \& Hsu, S. H. (2001). Perceptual factors underlying user preferences toward product form of mobile phones. International Journal of Industrial Ergonomics, 27, 247-258. http://dx.doi.org/10.1016/S0169-8141(00)00054-8

Gerpott, T., Rams, W., \& Schindler, A. (2001). Customer retention, loyalty, and satisfaction in the German mobile cellular telecommunications market. Telecommunication Policy, 25(4), 249-269. http://dx.doi.org/10.1016/S0308-5961(00)00097-5

Goode, M. M. H., Davies, F., Moutinho, L., \& Jamal, A. (2005). Determining Customer Satisfaction from Mobile Phones: A Neural Network Approach. Journal of Marketing Management, 21, 755-778. http://dx.doi.org/10.1362/026725705774538381

Han, S. H., Kim, K. J., Yun, M. H., Hong, S. W., \& Kim, J. (2004). Identifying Mobile Phone DesignmFeatures Critical to User Satisfaction. Human Factors and Ergonomics in Manufacturing, 14(1), 15-29. $\mathrm{http}: / / \mathrm{dx}$.doi.org/10.1002/hfm.10051

Hanken, A. (2010) Circularity of customer service experience and customer perceived value. Journal of Consumer Behaviour, 9(1), 37-53.

Işiklar, G., \& Büyüközkan, G. (2007). Using a multi-criteria decision making approach to evaluate mobile phone alternatives. Computer Standards \& Interfaces, 29, 265-274. http://dx.doi.org/10.1016/j.csi.2006.05.002

Laugesen, J., \& Yuan, Y. (2010). What factors contributed to success of Apple's iPhone? Ninth International Conference on Mobile Business, 91-99.

Lee, J. W. (2011). Critical factors promoting customer loyalty to Smartphone and mobile communications service providers. Academy of Marketing Studies Journal, 15(S1), 25-42. 
Nunnally, J. (1967). Psychometric Theory. New York: McGraw-Hill, 227.

Patterson, P. G. (1993). Expectations and Product Performance as Determinants of Satisfaction for a High $\begin{array}{llll}\text { Involvement Purchase. Psychology and Marketing, 10(5), 449-465. } & \text { and }\end{array}$ http://dx.doi.org/10.1002/mar.4220100507

Protalinski, E. (2012). Android grabs $75.0 \%$ market share in $\mathrm{q} 3$, followed by $14.9 \%$ for ios and $4.3 \%$ for blackberry. $\quad$ Retrieved from http://henextweb.com/mobile/2012/11/01/android-grabs-75-0-market-share-in-q3-followed-by-14-9-for-ios -and-4-3-for-blackberry/

Rockville, M. (2008). iPhone vs. BlackBerry-Which do consumers love most? New change wave survey reveals what owners really think about their smart phones, Public relation web article. Retrieved from http://www.prweb.com/releases/2008changewave/iphone_blackberry/prweb900914.htm

Taylor, S. A., \& Baker, T. L. (1994). An Assessment of the Relationship between Service Quality and Customer Satisfaction in the Formation of Consumers' Purchase Intentions. Journal of Retailing, 70(2), 163-178. http://dx.doi.org/10.1016/0022-4359(94)90013-2

\section{Appendix}

Reliability Test 1 (basic attributes)

\begin{tabular}{|c|c|c|c|}
\hline \multicolumn{4}{|c|}{ Reliability Statistics } \\
\hline \multirow[b]{2}{*}{ Cronbach's Alpha } & Cronbach's Alpha & Based & on \\
\hline & \multicolumn{2}{|l|}{ Standardized Items } & $\mathrm{N}$ of Items \\
\hline .764 & .751 & & 4 \\
\hline
\end{tabular}

\begin{tabular}{llll}
\hline Item Statistics & & & \\
\hline Items & Mean & Std. Deviation & $\mathrm{N}$ \\
It is easy to send text messages. & 3.78 & 1.767 & 100 \\
The ability to store phone numbers is sufficient. & 4.52 & 1.839 & 100 \\
The functional ability to talk is smooth. & 3.26 & 1.784 & 100 \\
Price is logical according to claims. & 4.15 & 1.226 & 100 \\
\hline
\end{tabular}

Reliability Test 2 (physical attributes)

\begin{tabular}{|c|c|c|}
\hline \multicolumn{3}{|c|}{ Reliability Statistics } \\
\hline \multicolumn{3}{|c|}{ Cronbach's Alpha Based on Standardized } \\
\hline Cronbach's Alpha & Items & $\mathrm{N}$ of Items \\
\hline .808 & .804 & 4 \\
\hline
\end{tabular}

\begin{tabular}{llll}
\hline Item Statistics & & & \\
\hline Items & Mean & Std. Deviation & $\mathrm{N}$ \\
The size of the smart phone is proper. & 4.78 & 1.801 & 100 \\
Physical design is attractive. & 4.27 & 1.746 & 100 \\
The smart phone is durable. & 4.78 & 1.801 & 100 \\
The color of smart phone is suitable. & 4.09 & 1.706 & 100 \\
\hline
\end{tabular}


Reliability Test 3 (user related attributes)

\begin{tabular}{lll}
\hline \multicolumn{2}{l}{ Reliability Statistics } \\
\hline \multicolumn{1}{c}{ Cronbach's Alpha } & \\
Cronbach's Alpha Items & N of Items \\
\hline .762 & .770 & 3 \\
\hline
\end{tabular}

\begin{tabular}{llll}
\hline Item Statistics & & & \\
\hline Items & Mean & Std. Deviation & $\mathrm{N}$ \\
It is very easy to Use. & 5.91 & 1.111 & 100 \\
Brand Image of smart phone is unique. & 5.33 & 1.484 & 100 \\
After sales service is quite satisfactory. & 4.99 & 1.360 & 100 \\
The color of smart phone is suitable. & 4.09 & 1.706 & 100 \\
\hline
\end{tabular}

Reliability Test 4 (technical attributes)

\begin{tabular}{|c|c|c|c|}
\hline \multicolumn{4}{|c|}{ Reliability Statistics } \\
\hline \multirow[b]{2}{*}{ Cronbach's Alpha } & Cronbach's Alpha & Based & on \\
\hline & Standardized Items & & $\mathrm{N}$ of Items \\
\hline .749 & .755 & & 4 \\
\hline
\end{tabular}

\begin{tabular}{llll}
\hline Item Statistics & & & \\
\hline & Mean & Std. Deviation & $\mathrm{N}$ \\
\hline Camera Quality of smart phone is excellent. & 5.46 & 1.445 & 100 \\
Operating System of smart phone is very sound. & 5.82 & 1.058 & 100 \\
Standby time is good. & 5.41 & 1.311 & 100 \\
Heat Emission is relatively Satisfactory. & 5.37 & 1.405 & 100 \\
\hline
\end{tabular}

Reliability Test 5 (value added attributes)

\begin{tabular}{|c|c|c|c|}
\hline \multicolumn{4}{|c|}{ Reliability Statistics } \\
\hline Cronbach's Alpha & $\begin{array}{l}\text { Cronbach's Alpha } \\
\text { Standardized Items }\end{array}$ & Based & $\begin{array}{l}\text { on } \\
\mathrm{N} \text { of Items }\end{array}$ \\
\hline .741 & .756 & & 6 \\
\hline
\end{tabular}

\begin{tabular}{llll}
\hline Item Statistics & & & \\
\hline Items & Mean & Std. Deviation & N \\
\hline Apps service is excellent to me. & 5.57 & 1.112 & 100 \\
GPS Capability is very trustworthy. & 5.48 & 1.218 & 100 \\
Heat Emission is relatively Satisfactory. & 5.37 & 1.405 & 100 \\
Touch screen service is outstanding. & 6.06 & .973 & 100 \\
iTunes store of smart phone is distinctive. & 5.57 & 1.112 & 100 \\
Accessories for smart phone are available. & 5.53 & 1.329 & 100 \\
\hline
\end{tabular}

\section{Correlations}

\begin{tabular}{|c|c|c|c|}
\hline & & Overall, how satisfied were you after using iphone. & Customer_Loyatly \\
\hline \multirow{2}{*}{\multicolumn{2}{|c|}{$\begin{array}{l}\text { Overall, how satisfied Pearson Correlation } \\
\text { were you after using Sig. (2-tailed) } \\
\text { iphone. }\end{array}$}} & 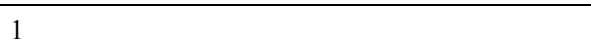 & $.360^{* *}$ \\
\hline & & & .000 \\
\hline & $\mathrm{N}$ & 100 & 100 \\
\hline \multirow[t]{3}{*}{ Customer_Loyatly } & Pearson Correlation & $.360^{* *}$ & 1 \\
\hline & Sig. (2-tailed) & .000 & \\
\hline & $\mathrm{N}$ & 100 & 100 \\
\hline
\end{tabular}

\footnotetext{
**. Correlation is significant at the 0.01 level (2-tailed).
} 
Multiple regression

\begin{tabular}{|c|c|c|c|c|c|c|c|c|c|}
\hline \multicolumn{10}{|c|}{ Model Summary $^{\text {b }}$} \\
\hline \multirow[b]{2}{*}{ Model } & \multirow[b]{2}{*}{$\mathrm{R}$} & \multirow[b]{2}{*}{ R Square } & \multirow[b]{2}{*}{ Adjusted R Square } & \multicolumn{3}{|c|}{ Change Statistics } & \multirow[b]{2}{*}{ df1 } & \multirow[b]{2}{*}{ df2 } & \multirow[b]{2}{*}{ Sig. F Change } \\
\hline & & & & \multicolumn{2}{|c|}{$\begin{array}{l}\text { Std. Error of the } \mathrm{R} \text { Square } \\
\text { Estimate }\end{array}$} & F Change & & & \\
\hline 1 & $.659^{\mathrm{a}}$ & .435 & .404 & $\begin{array}{ll}1.008 & .4\end{array}$ & 435 & 14.447 & 5 & 94 & .000 \\
\hline \multicolumn{10}{|c|}{ a. Predictors: (Constant), ValueAdded_Attributes, Basic_Attributes, User_Attributes, Physical_Attributes, Technical_Attributes } \\
\hline \multicolumn{10}{|c|}{ b. Dependent Variable: Overall, how satisfied were you after using Samsung smart phone. } \\
\hline \multicolumn{10}{|c|}{ ANOVA $^{\text {b }}$} \\
\hline \multicolumn{2}{|c|}{ Model } & & Sum of Squares & df & Mean Square & \multicolumn{2}{|l|}{$\mathrm{F}$} & \multicolumn{2}{|c|}{ Sig. } \\
\hline \multirow[t]{3}{*}{1} & & Regression & 73.397 & 5 & 14.679 & \multicolumn{2}{|c|}{14.447} & \multicolumn{2}{|c|}{$.000^{\mathrm{a}}$} \\
\hline & & Residual & 95.513 & 94 & 1.016 & & & & \\
\hline & & Total & 168.910 & 99 & & & & & \\
\hline
\end{tabular}

a. Predictors: (Constant), ValueAdded_Attributes, Basic_Attributes, User_Attributes, Physical_Attributes, Technical_Attributes.।

b. Dependent Variable: Overall, how satisfied were you after using Samsung smart phone.

\section{Coefficient}

\begin{tabular}{|c|c|c|c|c|c|c|c|c|}
\hline \multirow[b]{2}{*}{ Mode } & & \multicolumn{2}{|c|}{$\begin{array}{l}\text { Unstandardized } \\
\text { Coefficients }\end{array}$} & \multicolumn{3}{|l|}{$\begin{array}{l}\text { Standardized } \\
\text { Coefficients }\end{array}$} & \multicolumn{2}{|c|}{$95 \%$ Confidence Interval for B } \\
\hline & & $\mathrm{B}$ & Std. Error & Beta & $\mathrm{t}$ & Sig. & Lower Bound & Upper Bound \\
\hline \multirow[t]{6}{*}{1} & (Constant) & -.553 & .858 & & -.645 & .521 & -2.256 & 1.150 \\
\hline & Basic_Attributes & .093 & .105 & .092 & .888 & .377 & -.116 & .303 \\
\hline & Physical_Attributes & -.055 & .093 & -.060 & -.598 & .551 & -.240 & 129 \\
\hline & Technical_Attributes & .381 & .142 & .289 & 2.675 & .009 & .098 & .664 \\
\hline & User_Attributes & -.049 & .109 & -.041 & -.452 & .653 & -.265 & .167 \\
\hline & ValueAdded_Attributes & .732 & .166 & .449 & 4.422 & .000 & .403 & 1.061 \\
\hline
\end{tabular}

a. Dependent Variable: Overall, how satisfied were you after using Samsug smart phone.

\begin{tabular}{|c|c|}
\hline \multicolumn{2}{|c|}{ Collinearity Statistics } \\
\hline Tolerance & VIF \\
\hline .565 & 1.770 \\
\hline .603 & 1.657 \\
\hline .515 & 1.943 \\
\hline .728 & 1.373 \\
\hline .584 & 1.711 \\
\hline
\end{tabular}

\section{Copyrights}

Copyright for this article is retained by the author(s), with first publication rights granted to the journal.

This is an open-access article distributed under the terms and conditions of the Creative Commons Attribution license (http://creativecommons.org/licenses/by/3.0/). 